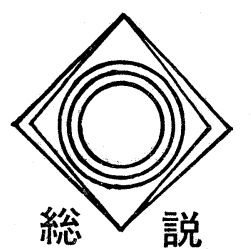

はじめに

熱供給事業法が昭和47年12月に施行されて 8 年にな る。

わが国に拈ける熱供給事業は, 現在までのところ, 個々の住宅，ビル等で行っている暖房および冷房の熱 源を集中化し, 一定の地域を単位として, ボイラー, 冷凍機などを設置したエネルギープラントから，おも に地中に埋設した導管を経て需要家に供給する，いわ ゆる「集中地域暖冷房」に代表されている。

エネルギー資源の大部分を外国に依存しているわが 国にとって，その有効利用を図ることは国をあげての 至上課題であり, さらに環境保全, 都市災害の防止等 の観点から, 都市再開発, ニュータウン造成などに関 連して事業が計画，実施されている次第である。

な扐，熱供給事業法による熱供給事業とは，主とし て「地域暖冷房事業」を予想したものであるが，たと えば, 工業用のプロセス蒸気の供給その他の事業形態 も含まれるので, 熱供給事業イコール地域暖冷房事業 ではなく,さらに, 供給対象および規模について一定 の要件を設けているので, 熱供給事業法に基づく地域 暖冷房事業以外のもの（たとえば, 組合方式その他自 家用のもの）も各地に存在しているが，本稿において は通産省が所管している熱供給事業法に基づく地域暖 冷房事業 (熱供給事業) について言及することになる 点, あらじめお断りしておきたい。

欧米に和ける地域暖房の歴史は，1810年代に始むる とされているが，本格的に地域暖房が行われるように なったのは第 2 次大戦後の1950年代以降のことであ る。わが国に括いては, 気候, 民度等の関係から洋風 暖房の採用は西欧諸国に比べて遅れていたが，昭和30 年代以降日本経済の高度成長と都市化の急激な進展に 伴う建築様式の変化によって, 個別の暖冷房が一般に 普及することとなった。

一方, 産業の発展に伴うェネルギー消費量の著しい

公益事業部計画課 東京都千代田区霞ケ関1-3
資源エネルギー庁成 田信 一

増加によって大気污染の問題が大きくクローズアップ され，他の活染物質の増加と相まって国民の生活と健 康に対して深刻な影響を与えるようになった。このよ うな背景のもとで各地で集中地域暖冷房計画が検討さ れることになった。もちろん, これ以前にも工場, 日 本駐留連合軍施設等でブロック式の暖房施設がなかっ たわけではないが，地域暖房に対する関心が急速に高 まってきたのは昭和40年以降のことである。

このような状勢に対応するため, 通産省としては昭 和45年に, 通産大臣の諮問機関である総合エネルギー 調査会に熱供給部会を設置して地域暖冷房に関する本 格的検討に入り，翌昭和 46 年に部会の中間答申が出さ れて, 都市に和ける地域暖冷房事業の必要性が強調さ れるとともに，保安確保と消費者保護の観点から熱供 給事業を電気事業，ガス事業に続く第三の公益事業と して事業規制すべき旨提言された。この答申を受けて 通産省は熱供給事業法の制定にふみきり, 昭和 47 年 6 月, 第68通常国会に拉いて熱供給事業法が成立, 公布 されたものである。

以下，わが国に和ける熱供給事業の現状を紹介し， 今後の方向について若干ふれることとずる。

\section{1. 熱供給事業の概略}

（1）はじめに，熱供給事業法について，その基本的な 考え方を紹介して扮きたい。

本法のねらいは一言でいうと，(1)事業が一度開始さ れれば，事業者はその区域に拈いて独占的な地位を有 するに至ること。(2)したがって，継続安定的な供給が 確保され，また，不当な料金にならないよう消費者の 立場に立った事業の監督が必要であること。(3)公道に 埋設される導管等の設置については，従来保安規制が なされていないため法的規制を行らこと, などにより 公益事業として位置付け，あわせて税制，金融等の助 成措置を講ずるというものである。

本法上, 熱供給事業とは, 一般の需要（いわゆる不 特定多数の需要) に応じて, 加熱され, もしくは冷却 された水または蒸気を導管により供給する事業で，供 
給設備の能力が 5 ギガカロリ一毎時 $\left(\mathrm{G} \mathrm{cal}=10^{9} \mathrm{cal}\right)$ 以上のものとされている。

「熱」の供給という概念を用いなかったのは，たと えば冷水を循環させて冷房を行う場合には，むしろ熱 を奪っているのであって「供給」といい難い等定義と して不明確さが残るためであるが，ここでいら供給に は，温水または蒸気をそのまま直接に供給する場合に とどまらず，送った温水または蒸気がその保有する温 度を減じ，利用価值を失って戻ってくる循環方式の場 合も, その熱エネルギーとしての価值に着目して含ま れるものとしている。

（2）わが国に打ける熱供給事業の現状（表 1 参照）

現在の熱供給事業は昭和 45 年 2 月に供給開始した大 阪瓦斯株 の千里ニュータウン地点をはじめとして，北 海道から九州まで30地点（20社）となっており，いず れもニュータウン, 卸売団地の造成計画, 都市再開発 計画，既成市街地の熱源統合等との関連において集中 暖冷房が計画され実施されているものである。

(2)-1 需要形態, 地域分布, 事業主体は次のと括り である。

住 宅用: 北海道地域 7 , その他地域 4

業 務 用: 北海道地域 3 , その他地域 16

事業主体：熱供給専業17社

公益事業, 不動産業による兼業 3 社

(2)-2 事業規模は次のとおりである。

$\begin{array}{rr}\text { 需要家件数 : 住宅用 } & 24,051 \text { 件 } \\ \text { 業務用 } & 580 \text { 件 }\end{array}$

供給対象面積（暖冷房延べ面積）

$\begin{array}{ll}\text { 住宅用 } & 2,333,177 \mathrm{~m}^{2} \\ \text { 業務用 } & 6,265,757 \mathrm{~m}^{2}\end{array}$

熱需要量 : (昭和54年度販売実績)

住宅用温熱（暖房および給湯）

209, $915 \mathrm{G} \mathrm{cal}$

業務用：温熱 $470,819 \mathrm{G}$ cal

冷熱 $248,856 \mathrm{G} \mathrm{cal}$

設備容量 : ボイラー 95 基 $881.3 \mathrm{G} \mathrm{cal} / \mathrm{H}$

冷凍機 84基 $324.1 \mathrm{G} \mathrm{cal} / \mathrm{H}$

(107, 200 RT)

熱交換器 9 基 $50 \mathrm{G} \mathrm{cal} / \mathrm{H}$

導管 : 本支管総延長 $198,874 \mathrm{~m}$ 供給管総延長 $99,328 \mathrm{~m}$

従業員数（含常勤役員） 502 人

燃料使用量（昭和54年度実績）

都市ガス $54,830,687 \mathrm{~m}^{3}$ ( 1 万キロカロ リ一換算)

$$
\begin{array}{lr}
\text { 石炭 } & 36,465 \mathrm{t} \\
\text { 灯油 } & 27,338 \mathrm{k} \ell \\
\text { 重油 } & 20,317 \mathrm{k} \ell \\
\text { 再生油 } & 837 \mathrm{k} \ell \\
\text { 以上のほか } &
\end{array}
$$

工場廃熱 $148,584 \mathrm{t}$

冷凍機に拈ける冷熱製造用としての使用 電力量が 73, 200, $197 \mathrm{kWh}$ あ。

使用然料は以上のと抢りであるが，石炭は札幌 市の都心部地点のそれであり, 工場廃熱は, 札幌 市の厚別清掃工場, 大阪市の森の宮清掃工場, 日 本化成 (小名浜) のコークス炉の廃熱を, それぞ れ隣接する下野幌団地, 森の宮団地, 小名浜地区 が熱源として有効利用しているものである。

一般的にいえば, 現在の然料使用状況として は,

大都市部に括いては都市ガス，その他地域にお いては，都市ガス，灯油の併用和よび灯油ないし 重油となっている。

売 上 高：(昭和54年度実績)

住宅用温熱 (暖雱, 給湯)

$\begin{array}{cl} & 3,375,745 \text { 千円 } \\ \text { 業務用温熱 } & 7,454,473 \text { 千円 } \\ \text { " 冷熱 } & 7,431,098 \text { 千円 }\end{array}$

料金体系：定額料金制（集合住宅の暖房につい て，暖房面積当りの定額料金） 基本料金扗よび従量料金の二部料金制 （給湯，個人住宅の暖房，業務用に 適用)

料金水準：熱料金は熱供給事業法に基づいて原価 主義の観点から各地点毎に認可されて いる。したがって，設備投資時期，供 給システムなどの相異に加え, 資金コ ストの差および工事費負担金の有無な ぞによる資本費負担の差がある他, 使 用然料の相異によるエホルギーコスト の差などにより, 各地点毎の料金水準 は画一的なものにはなっていないが, たとえば，北海道地区に括ける住宅用 の場合についてみると，暖房および給 湯の総平均単価は, メガカロリ一当り 14円から19円程度の水準になってい る。また，大都市に打ける業務用の場 合については温熱の総平均単価は, 16 円から50円程度, 冷熱のそれは32円か 
表 1 熱供給事

\begin{tabular}{|c|c|c|c|c|c|}
\hline No. & 事 業 者 名 & 本 社 所 在 地 & 代表者 & $\begin{array}{l}\text { 凟本金 } \\
\text { (億円) }\end{array}$ & 供 給 区 域 \\
\hline 1 & 株) 北海道蓺供給公社 & $\begin{array}{l}060 \\
\text { 札沮市中央区北 } 2 \text { 条西 } 3 \text { 丁目 } \\
\text { 敷島ビル内 } \\
\text { (011) } 241-4401\end{array}$ & 小塩 進作 & 20.0 & 札幌市都心部 \\
\hline 2 & 北海 道 地 域 暖 房 (㫼) & $\begin{array}{l}060 \\
\text { 札幌市中央区大通西 } 5 \text { 丁目 } 11 \\
\text { 大五ビル } \\
\text { (011) 241-0026 }\end{array}$ & 西原 由治 & 8.0 & 札帨市下野幌団地 \\
\hline 3 & 北広 鼻 熱 供 給 (株) & $\begin{array}{l}061-11 \\
\text { 北海道札幌郡広島町輝美町2-2 } \\
\text { (01137) 3-2122 }\end{array}$ & “讃良 & 13. 0 & 北海道北広島団地 \\
\hline 4 & 苫小牧熱サービス (侏) & $\begin{array}{l}053 \\
\text { 苫小牧市日新町3-5-6 } \\
\text { (0144) 73-1131 }\end{array}$ & 河端 & 1.65 & 苫小牧市日新団地 \\
\hline 5 & 株)苫小牧エネルギー公社 & $\begin{array}{l}053 \\
\text { 苫小牧市末広町1-16-13 } \\
\text { (0144) 33-4310 }\end{array}$ & 土川 清 & 4.95 & 苫小牧市街地南地区 \\
\hline 6 & 苫 小牧 熱 供 給 (侏) & $\begin{array}{l}053 \\
\text { 苫小牧市大成町1-11-25 } \\
\text { (0144) 74-3141 }\end{array}$ & 油谷 昌平 & 3.2 & $\begin{array}{l}\text { 苫小牧市弥生町，大 } \\
\text { 成町，青葉町 }\end{array}$ \\
\hline 7 & 函 館、熱 供 給 (秼) & $\begin{array}{l}041 \\
\text { 函館市西桔梗町589-52 } \\
\text { (0138）49-3037 }\end{array}$ & 片岡宏 & 0.9 & 函館圈流通センター \\
\hline 8 & 石 狩サーービ ス (株) & $\begin{array}{l}061-32 \\
\text { 北海道石狩郡石狩町花川北 } 3 \\
\text { 条 } 1 \text { 目 } 7 \\
(01336) 4-5001\end{array}$ & 斎藤 常夫 & 3.0 & 北海道花畔団地 \\
\hline 9 & 小名 浜 配 湯 (株) & $\begin{array}{l}971 \\
\text { いわき市小名浜字定西71 } \\
\text { (0246) 53-4305 }\end{array}$ & 青木 正夫 & 0.3 & いわき市小名浜 \\
\hline & & & & & 新，宿 副 都 心 \\
\hline 10 & 東 京 互 斯 & $\begin{array}{l}103 \\
\text { 東京都中央区八重洲1-2-16 } \\
\text { (03）273-0111 }\end{array}$ & 村上 武雄 & 1,050 & 成由ニュータウン \\
\hline
\end{tabular}




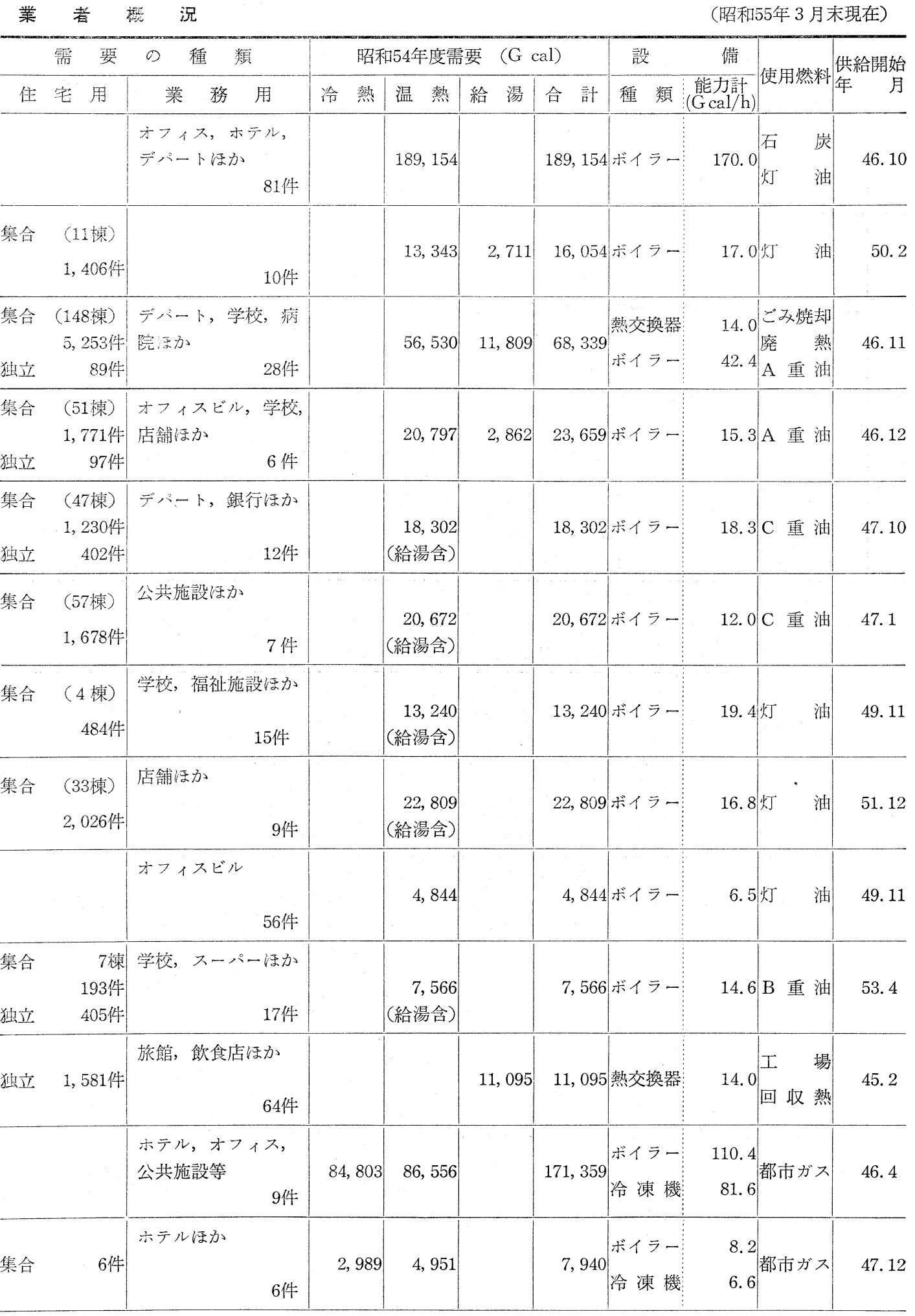




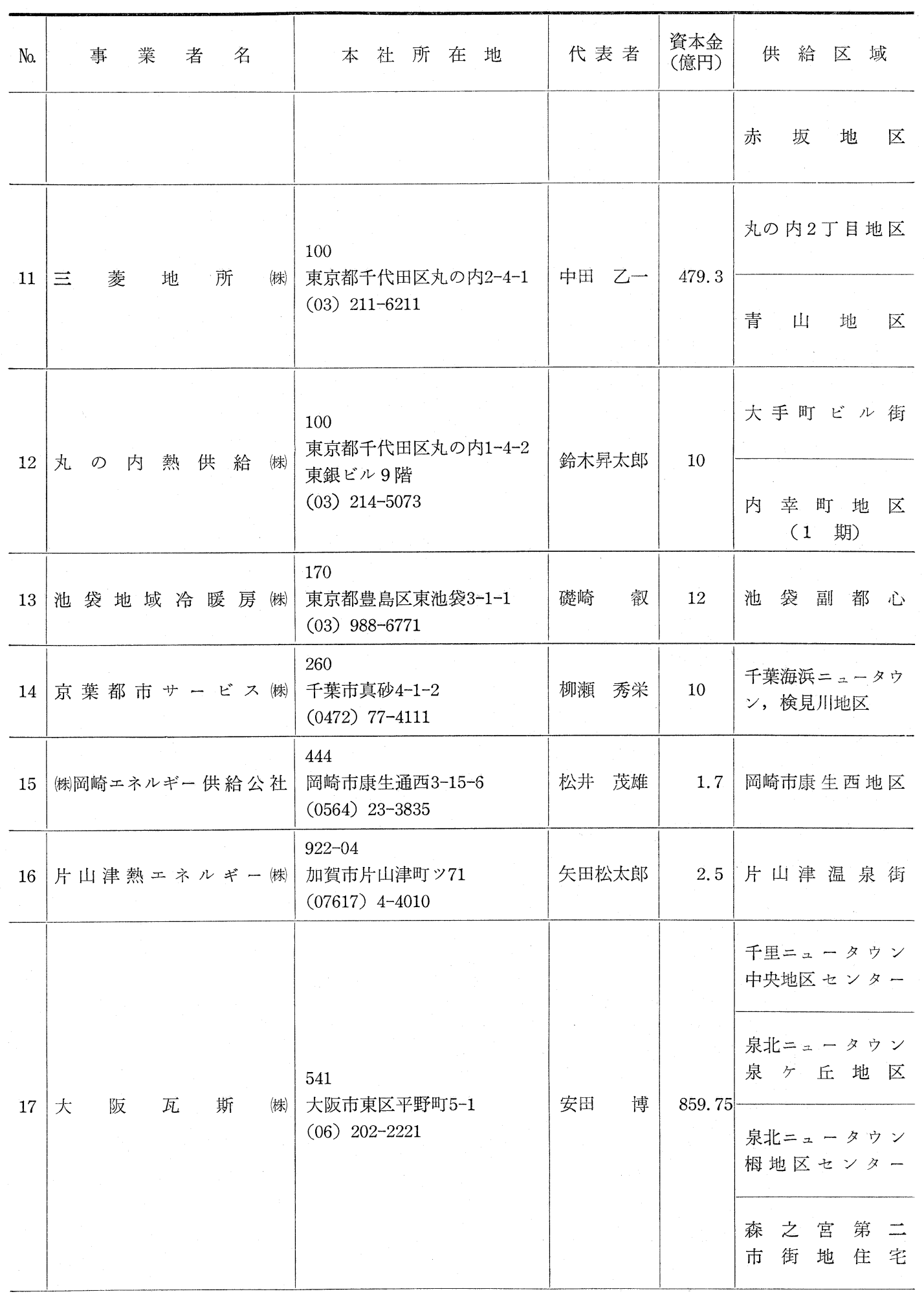




\begin{tabular}{|c|c|c|c|c|c|c|c|c|c|c|}
\hline & 需 要 & の 種 顔 & 昭和: & 口54年度需 & 要 (G ca & & 設 & 備 & & 供給開始 \\
\hline \multirow[t]{6}{*}{ 住 } & 宅 用 & 業 務 用 & 冷 熱 & 温 熱 & 給 湯 & 合 計 & 種 類 & $\begin{array}{l}\text { 能力計 } \\
(\mathrm{G} \text { cal } / \mathrm{h})\end{array}$ & & \\
\hline & & $\begin{array}{l}\text { オフィス，地下鉄駅 } \\
\text { 舎ほか } \\
\\
\text { 3件 }\end{array}$ & $\begin{array}{c}7,107 \\
\text { (計画) }\end{array}$ & $\begin{array}{c}3,116 \\
\text { (計画) }\end{array}$ & & $\begin{array}{c}10,223 \\
\left(\begin{array}{c}1 \\
\text { (計画) }\end{array}\right.\end{array}$ & $\begin{array}{l}\text { ボイラー } \\
\text { 冷 凍 機: }\end{array}$ & $\begin{array}{l}16.2 \\
10.3\end{array}$ & 都市ガス & $\begin{array}{c}55.10 \\
\text { (予定) }\end{array}$ \\
\hline & & $\begin{array}{ll}\text { オフィスビル } & \\
& \text { 8件 } \\
\end{array}$ & & 23,296 & & 23,296 & ボイラー & 60.6 & 都市ガス & 48.12 \\
\hline & & \begin{tabular}{|l|} 
オフィスビル，地下 \\
鉄駅舎浪か \\
\\
4 4件
\end{tabular} & 8,061 & 4,280 & & 12,341 & $\mid$\begin{tabular}{|} 
ボイラー \\
冷 凍 機
\end{tabular} & $\begin{array}{r}12.9 \\
9.7\end{array}$ & 都市ガス & 53.11 \\
\hline & & \begin{tabular}{|l|} 
オフィスビル，地下 \\
鉄駅舎 \\
\end{tabular} & 35,063 & 33,387 & & 68,450 & $\mid \begin{array}{l}\text { ボイラー } \\
\text { 冷 凍 機 }\end{array}$ & $\begin{array}{l}73.8 \\
44.1\end{array}$ & 都市ガス & 51.4 \\
\hline & & \begin{tabular}{|l} 
オフィスビル，地下 \\
鉄駅舎 \\
\end{tabular} & 130 & 972 & & 1,102 & 冷 凍 機 & $\begin{array}{l}22.7 \\
10.9\end{array}$ & 都市ガス & 55.2 \\
\hline 集合 & 246 件 & 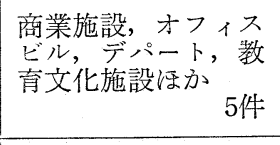 & 44,231 & 20,452 & & 64,683 & $\left|\begin{array}{l}\text { ボイラー } \\
\text { 冷 凍 機 }\end{array}\right|$ & $\begin{array}{l}45.2 \\
56.8\end{array}$ & 都市ガス & 53.4 \\
\hline \multirow[t]{3}{*}{ 集合 } & 2,840 件 & 銀行 & & $\begin{array}{r}9,280 \\
\text { (給湯含) }\end{array}$ & & 9,280 & ) ボイラー & 30.0 & 都市ガス & 49.4 \\
\hline & & $\begin{array}{l}\text { デパート,オフィス, } \\
\text { ホテル浪か } \\
\end{array}$ & 7,993 & 2,303 & & 10,296 & 泠イラー & $\begin{array}{r}7.7 \\
10.5\end{array}$ & 都市ガス & 47.10 \\
\hline & & \begin{tabular}{|l} 
温泉街 \\
26件 \\
\end{tabular} & & 30,459 & & 30,459 & ボイラー & 32.3 & $\begin{array}{lll}A & \text { 重 } & \text { 油 } \\
B & \text { 重 } & \text { 油 }\end{array}$ & 50.11 \\
\hline 集合 & $\begin{array}{r}5 \text { 棟 } \\
5 \text { 件 }\end{array}$ & $\begin{array}{r}\text { ホテル, デパート, } \\
\text { オフィス涹か } \\
16 \text { 件 }\end{array}$ & 41,004 & 18,295 & & 59,299 & $\left\{\begin{array}{l}\text { ボイラー } \\
\text { 冷 凍 機 }\end{array}\right.$ & $\begin{array}{l}38.9 \\
44.5\end{array}$ & 都市ガス & 45.2 \\
\hline \multirow[t]{2}{*}{ 集合 } & \begin{tabular}{r|}
20 棟 \\
7 件
\end{tabular} & $\begin{array}{rr}\text { デパート, スーパー, } \\
\text { 病院添か } \\
& 7 \text { 件 }\end{array}$ & 8,895 & 21,080 & & 29,975 &  & $\begin{array}{l}25.6 \\
11.2\end{array}$ & 都市ガス & 46.6 \\
\hline & & $\begin{array}{r}\text { スーパーオフィス, } \\
\text { 文化センター注か } \\
3 \text { 件 }\end{array}$ & 1,393 & 1,017 & & 2,410 & $\left\{\begin{array}{lr}\text { ガ } & \text { ス } \\
\text { 冷暖房機 }\end{array}\right.$ & 4.5 & 都市ガス & 49.8 \\
\hline 集合 & $\begin{array}{r}\text { 棟 } \\
1,279 \text { 件 }\end{array}$ & 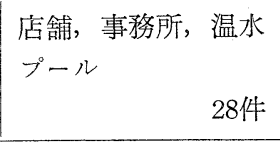 & & 8,103 & 3,573 & 11,676 & $\mid \begin{array}{l}\text { 熱交換器 } \\
\text { ボイラー }\end{array}$ & $\begin{array}{l}22.0 \\
10.8\end{array}$ & $\mid \begin{array}{lr}\text { ごみ焼却 } \\
\text { 廃 } & \text { 熱 } \\
\text { 都市ガス }\end{array}$ & 51.5 \\
\hline
\end{tabular}




\begin{tabular}{|c|c|c|c|c|c|}
\hline No. & 事 業 者 名 & 本 社 所 在 地 & 代表者 & $\begin{array}{l}\text { 資本金 } \\
\text { (億円) }\end{array}$ & 供給 区域 \\
\hline 18 & 芦屋浜エネルギーサービス(㑣) & $\begin{array}{l}659 \\
\text { 芦屋市高浜町 } 7 \text { 番2-201 } \\
\text { (0797) 34-0725 }\end{array}$ & 吉田 㴏次 & 0.5 & 声屋浜滈層住宅地区 \\
\hline 19 & 福 岡 熱 供 給 (秼) & $\begin{array}{l}810 \\
\text { 福岡市中央区渡辺通1-1-1 } \\
\text { サンセルコビル } 8 \text { 階 } \\
\text { (092) } 712-4421\end{array}$ & 中村 万一 & 4.8 & \begin{tabular}{|l} 
福岡流通センター地区 \\
渡沼通再開発地区
\end{tabular} \\
\hline 20 & 九州地域冷暖 房 (侏) & $\begin{array}{l}802 \\
\text { 北光州市小倉北区浅野 } \\
3-5-27 \\
\text { (093) } 521-5065\end{array}$ & 岸本 孟 & 4 & 小含駅周㲽地区 \\
\hline
\end{tabular}

合計

(訫画除)

ら70円程度のものとなっている。

(2)-3 熱供給事業が当面している問題点

現在の熱供給事業の概要は以上述べたと拈りで㐫 り, 新しい産業として, まだその緒についたばかりで あるが，10年前に都市の新しいユーティリティとして はなばなしくスタートした割には，その後の諸情勢の 変化により各事業の経過は当初の予想に比べはるかに 厳しいるのとなり, 現在, 種々の問題を提起するとこ ろとなっている。いずれる集約すると, 経営上の問題 に帚結されるるので第る。

熱供給事業は, 多額の固定資産を抱兄る装置産業で あり投下資本の回收には長期間を要するものである が，一般的に先行投資を避けられないこと，さらには 需要が不確実であるという事情も㟧って投下資本の回 収不足が生じやすい。ニュータウン計画あるい性都市 計画は相当長期間にわたって実施されるが，熱供給施 設とくに基幹的な導管については，最終規模に匹適す る設備を当初から先行的化設置することになる上，経 済情勢の変更などにより計画需要の顕在化に変動が生 じやすいためである。おた，昨今のエネルギー事情の 切迫を反映して燃料費等の高騰によりコスト增となっ ても，熱料金の值上がスムーズに実施できない現状も 無視できない。

一般飞, 熱供給事業は事業開始当初は赤字経営を余 儀なくされるが，需要增加に伴ない序々に収支状況を
好転させ，遅くも10年間程度で累積赤字を解消し，以 後の経営を安定させなければならないと考えられてい るが, 現在稼動中の 29 地点の中, 1 地点を除いて他は すべて累積赤字を抱えている状況にある。操業間もな い地点は必然の帰結とい光るが，10年程度経過した地 点についても同様である点が問題となっている次第で ある。

これらの原因は「料金のあり方」にそのすべての根 源があると考光られるが，この点の解明は本稿ではな じみが少ないので，定性的父㑯面の理由定一，二指摘 するにとどめたい。その第 1 は, 計画規模の縮少もし くは幄延による熱需要の減少で市る。先行投資を余義 なくされる上に, 将来の一定規模を前提として設備投 資を行うのであるから，需要減は致命的化固定費用の 回収不足を招くことになる。第 2 は，然料費をはじめ とする変動費用の急增傾向である。熱精金は公益事業 として料金規制の対象となって拈り，可及的飞安定性 が要請されているが，昨今のように燃料等の価格変動 の激しい場合には，適正な原価侸らして妥当な料金 の算定がきわめて困喤でめる。このため料金改訂が後 追いの形となって，費用の料金化化当って積死残しを 招くことになる。

さらに, 他の公益事業と異なり, 需要側に代替手段 がせるため，原価主義に基づく料金の強要には自ずと 限界があり，適正な料金水準の維持が困難な場合る出 


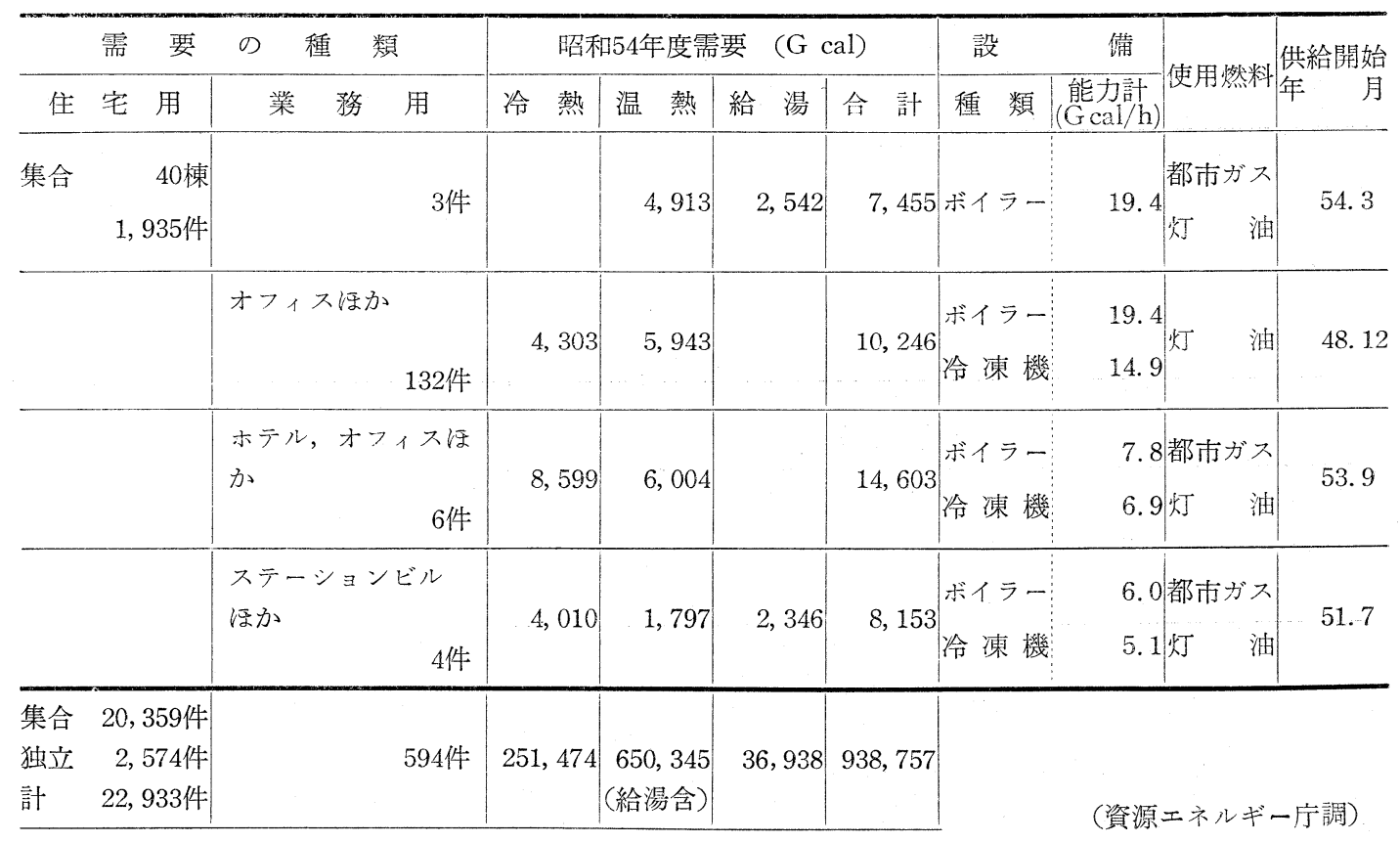

てくる。

古い地点では, 昭和 48 年の第 1 次石油ショック以 来, 料金改訂は汪ほ三巡しているが，そのつど以上の ような事情が繰返されている次第である。

地域暖冷房のメリットを，個別暖冷房と比較する場 合に扔いて，直接的なコストのみでその優劣が論じら れる傾向が強く, 安全性, 利便性, 省力化などの無形 の価值が正しく評価されていない憾みがあるのも事実 である。

事業化に当っては, 適正な需要想定に基ら゙く設備対 応と適切な需要確保対策が必須の要件で第ることはい らまでもないが，地域のコンセンサスにも十分配慮を 要する必要があり,この点は最近の新しい地点の事業 化に際して大きい教訓となっている。

\section{2. 惠例の紹介}

わが国に和ける熱供給事業の典型的な事例として, 東京瓦斯秼が新宿副都心に和いて実施している地域暖 冷房と工場廃熱を有効に利用して地域暖房を行ってい る北海道地域暖房株の下野昵地点を紹介してみよう。

(1) 新宿副都心地点

本地点は東京都の副都心計画に対応し, 旧淀橋浄水 場跡地 (16.4万 $\mathrm{m}^{2}$ ) の11ブロックを対象として, 東京 瓦斯㧣により計画され, 昭和46年 4 月から供給が開始 されている。最終規模はボイラー設備で $290 \mathrm{~T} / \mathrm{H}$, 冷 凍設備で $41,000 \mathrm{R}$ Tに及ぶ規模となるものである。需
要家は昭和46年に完成した京王プラザ ホテルをはじ め, 新宿住友ビル, 国際電々ビル, 新宿三井ビル, そ の他いずれも超高層ビルで, 現在の需要家は 9 棟とな っている。

設備概要は表 2 のと和りである。プラント設備はボ イラー設備としては水管ボイラーを, 冷凍設備として は復水タービン駆動ターボ冷凍機を採用して和り, 現 在までのところボイラー設備は60 T/Hを主として150 $\mathrm{T} / \mathrm{H}$, 冷凍機設備は7, 000 R Tを主として27,000R T の設備を完成しているが, 最終規模としては, ボイラ $-290 \mathrm{~T} / \mathrm{H}$, 冷凍機設備 $41,000 \mathrm{R} \mathrm{T}$ の計画となってい る。な特, 地域配管は昭和 51 年に安田火災海上ビル向 けの配管を完成した時点ですでに $95 \%$ 相当を敷設した が，現在ではほほ最終規模に相当する配管が完成して いる。

熱負荷については表 3 のよらな最大負荷および年間 負荷を想定して事業計画が行われたが，その後の実績 に特いては気候条件その他により若干の高低はあるが 大体のところ想定に近い值となっている。

供給条件としては, 蒸気及び冷水を 4 管式で通年供 給して和り，熱煤供給条件は表4のと赫りである。

(2) 下野棍地点

本地点は本格的な住宅団地を主軸とし, 副都心業務 施設を含めた札帵市の長期計画に呼応して, 北海道地

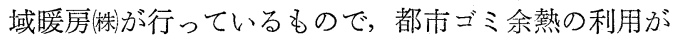


表 2 政新宿地域冷暖房センター設㵝概要

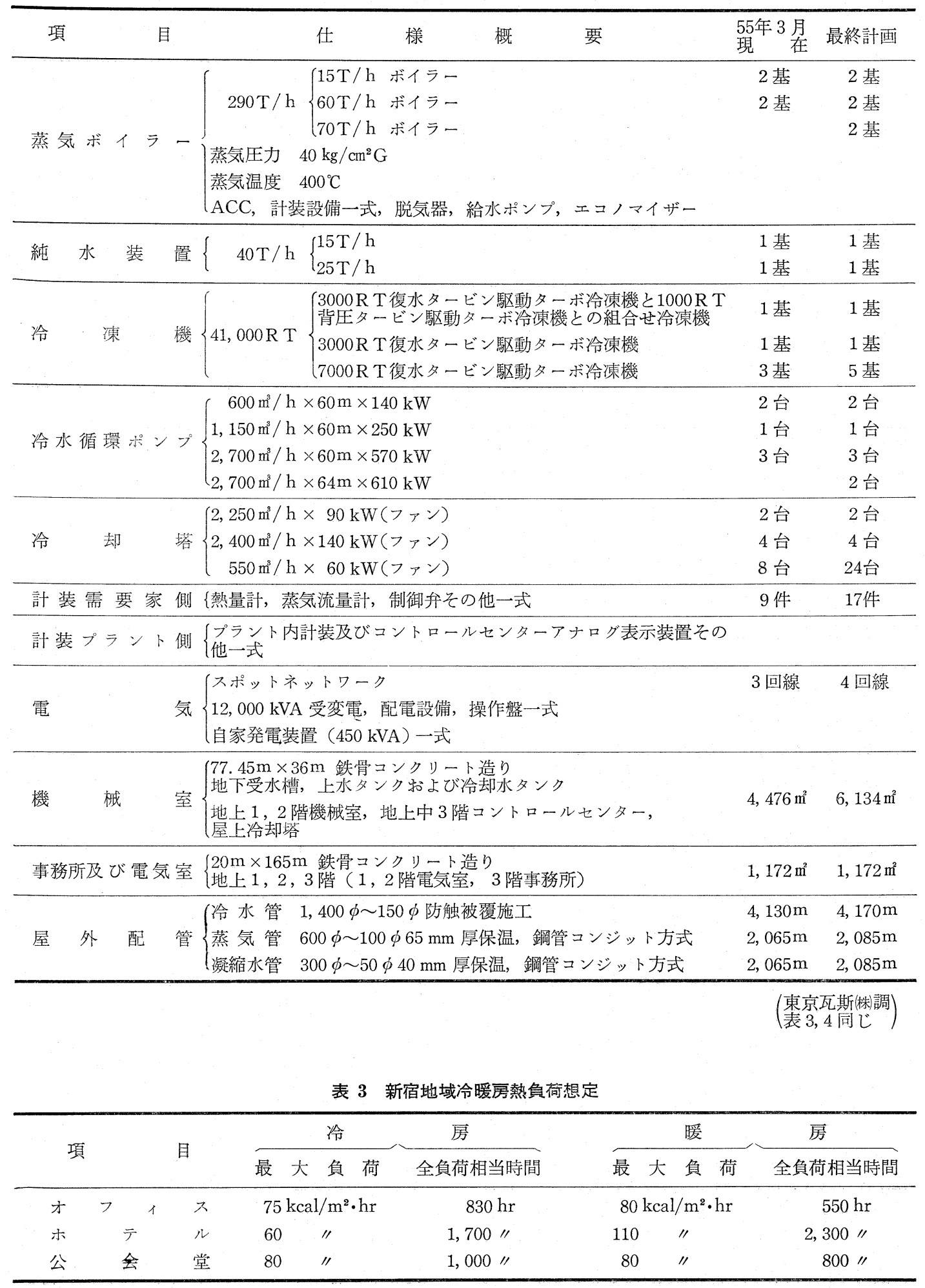




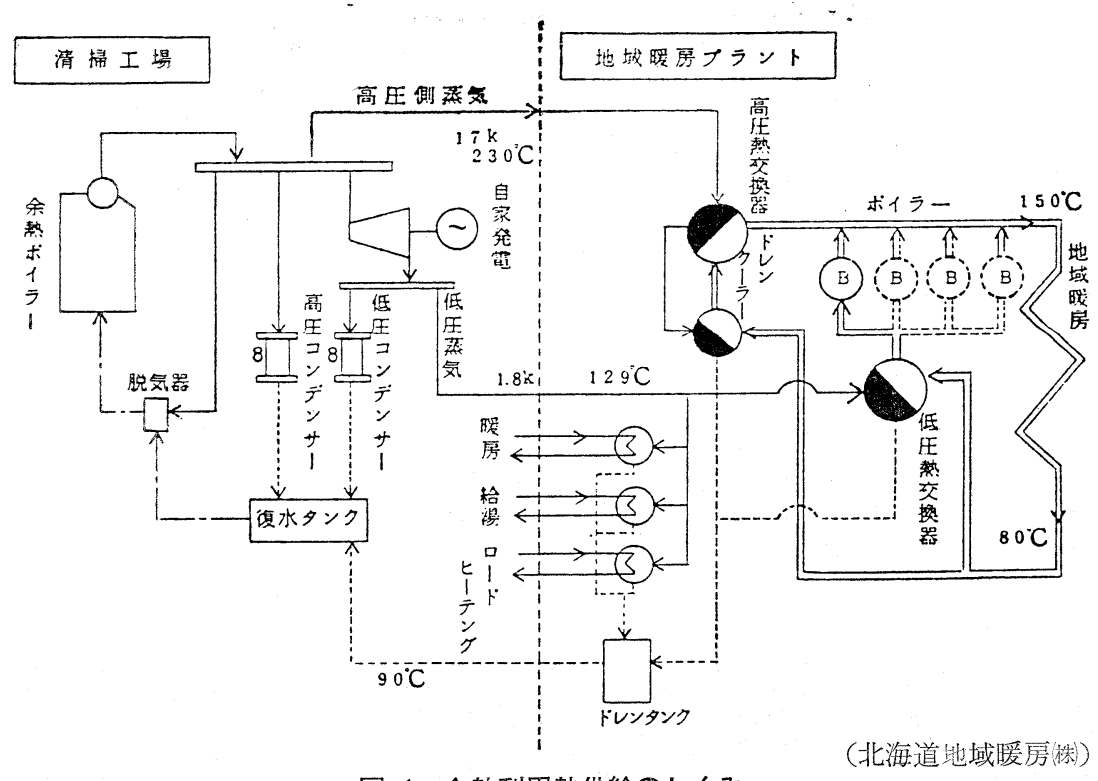

図 1 余熱利用熱供給のしくみ

表 4 新宿地域冷暖房熱媒供給条件

\begin{tabular}{|c|c|c|c|}
\hline \multirow{2}{*}{ 熱媒の種類 } & 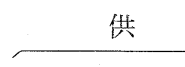 & 条 & 件 \\
\hline & 圧 & $\left(\mathrm{kg} / \mathrm{cm}^{2} \mathrm{G}\right)$ & 温度 $\left({ }^{\circ} \mathrm{C}\right)$ \\
\hline 泹執 $\int$ 蒸気 & 7.0 & & 飽和 \\
\hline 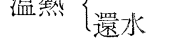 & $1.2 \sim 2.8(\mathrm{~T}$ & P 43m基準) & - \\
\hline 冷埶 $\{$ 冷水（往 & $8.6 \sim 10.6 C$ & "I) & 4 \\
\hline 䦽篮 $\{$ 冷水（返 & $6.6 \sim 8.6 C$ & $11)$ & 12 \\
\hline
\end{tabular}

当初から計画に織込まれている。本地点は昭和46年11 月に供給開始したが，昭和49年12月からは札幌市厚別 清掃工場のゴミ焼却余熱の利用が行われた。熱料金に 占める燃料コストは，余熱利用といら低コスト条件か ら，石油系然料を使用している北海道内の他の地域暖 房地点に比べて, 熱料金も安いものとなって和り, 石 油ショック以来再度実施を余儀なくされた料金改訂に 特いても，その值上幅が比較的少いもので势った。余 熱利用の概要は次のと㔚りである。

清掃工場側の余熱発生量は, ゴミ質 $1,250 \mathrm{kcal} / \mathrm{kg}$ の 場合で, 焼却量 $600 \mathrm{~T} / \mathrm{D}$ から, 蒸気発生量 $40.3 \mathrm{~T} / \mathrm{H}$ (蒸発倍数1.6), 発電 $(1,400 \mathrm{~kW})$ など清掃工場側所 内使用分 $27.4 \mathrm{~T} / \mathrm{H}$ で，地域暖房側へくる余熱惊，発 電タービンを経た低圧蒸気 $1.8 \mathrm{atg}, 129^{\circ} \mathrm{C}$ ものが $18.1 \mathrm{~T} / \mathrm{H}$, 高圧蒸気 $17 \mathrm{atg}, 230^{\circ} \mathrm{C}$ ののが $12.9 \mathrm{~T} / \mathrm{H}$ になる。これを $90^{\circ} \mathrm{C}$ の復水で清掃工場へ戻すことにな
っているので，利用できる熱量は $17.3 \mathrm{Gcal} / \mathrm{H}$ であ る。

本地点は, 現在約 5,300 戸の集合住宅, 約 90 戸の個 別住宅，スーパー，小学校その他の業務施設への熱供 給を行っているが，全供給量に占めるゴミ余熱分は昭 和54年度で約75\%となっている。この余熱利用率は， 過去逐年增加をみせた熱需要と共に上昇し, 昭和50年 度約70\%，51年度約 $86 \% ， 52$ 年度約 $85 \%$ であったが， その後は熱需要の增加が大きくなったため相対的に辢 減傾向を示している。な括，余熱発生側からみた利用 率は，50年度 $30 \%$ 台，51年度 $40 \%$ 台，52年度 $60 \%$ とな っている。本地点の場合は60\%台の利用率がピークで 残余の $40 \%$ \%か利用になっているが，これはほとんぞ 夏期のもので, 冷房需要が少いこと, 深夜の利用性の ないことなどによるもので每る。

一般に，ゴミ焼却余熱利用については，

(1) ゴミの種類（場所，時期など）によって，その 発熱量に差があるため, 余熱発生量が一定でな い。

(2) ゴミ焼却装置のオーバーホールなどによる停止 めるいは能力ダウンがある。

(3) ゴミ焼却工場側としては当然，焼却が主で熱利 用が従となり運転状況もゴミ焼却ペースになる。 などの事情があるため, 熱供給体制としては供給され ろ余熱能力相当の予備ボイラーの設置が必要となる, 
表 5 熱供給事業（集中地域暖冷票事業）の新果

\begin{tabular}{|c|c|c|}
\hline 効果 & & 効 \\
\hline $\begin{array}{l}\text { 環 } \\
\text { 境 } \\
\text { 効 } \\
\text { 果 }\end{array}$ & $\left\{\begin{array}{l}\text { 公書 防 } \text { 止 } \\
\text { 居 住 環 境, } \\
\text { 快 適 性 向 } \\
\text { 都市美 観 向上 }\end{array}\right.$ & 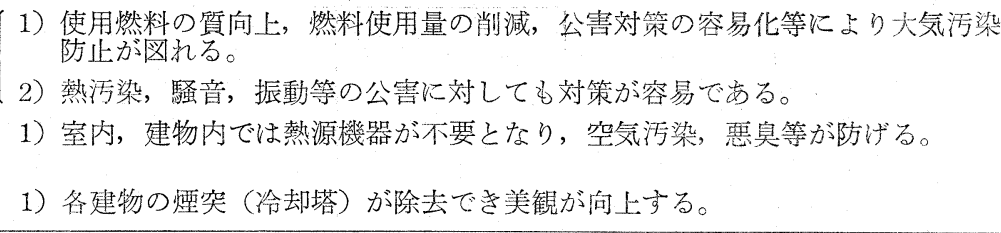 \\
\hline $\begin{array}{l}\text { 利 } \\
\text { 峺 } \\
\text { 效 } \\
\text { 果 }\end{array}$ & $\left\{\begin{array}{l}\text { 利 便 性 向上 } \\
\text { 管理精度 向上 } \\
\text { 都市エネルギ一 } \\
\text { 管理機能高度化 }\end{array}\right.$ & $\begin{array}{l}\text { 1) 各個に打ける熱源機器の運転操作（含燃料運搬）が不要となる。 } \\
\text { 1) 集中化により管理機器，管理方法が高度化し，高性能が維持できる。 } \\
\text { 1）都市エネルギー供給の管理化により広域コントロールが可能となり，污染制 } \\
\text { 御，防災管理が容易になる。 }\end{array}$ \\
\hline $\begin{array}{l}\text { 経 } \\
\text { 斎 } \\
\text { 効 } \\
\text { 果 }\end{array}$ & 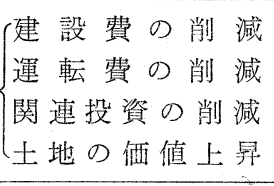 &  \\
\hline $\begin{array}{l}\text { 安性 } \\
\text { 全効 } \\
\text { 宋 } \\
\text { 宽 } \\
\end{array}$ & 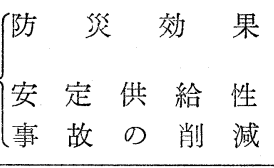 & 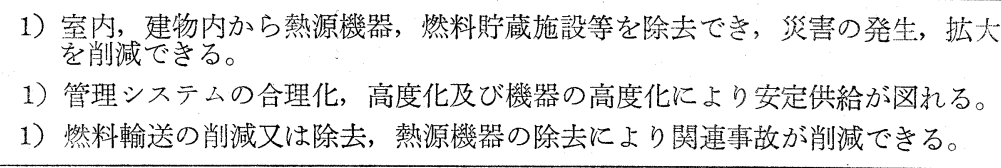 \\
\hline $\begin{array}{l}\text { 省ギ算 } \\
\text { ネ. } \\
\text { ル省 }\end{array}$ & $\left\{\begin{array}{l}\text { 省エネルギー効果 } \\
\text { 買 }\end{array}\right.$ & $\begin{array}{l}\text { 1）廃熱利用，効率向上等によりエネルギー使用量が削減できる。 } \\
\text { 1）稼動率向上等により，地区全体の設備容量が削減できる。 } \\
\text { 2) ピークカットによ電力供給設備の容量が削減できる。 }\end{array}$ \\
\hline $\begin{array}{l}\text { 勂用 } \\
\text { 間効 } \\
\text { 利果 }\end{array}$ & 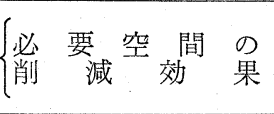 & $\begin{array}{l}\text { 1）熱源機器関連で必要な空間の除去, 削減が可能となる。 } \\
\text { 2）負荷増加に対処するための余裕スペースの確保ぶ不要となる。 }\end{array}$ \\
\hline
\end{tabular}

等の問題がめるが，本地点の廃熱利用システム叔よび その運用状況は，時代の要請に十分応えるものになっ ていると考えられる。

\section{3. 熱供給專業のあり方}

さきにも述べたと初り，熱供給事業としての地域暖 泠房は，過密化した都市の大気活染防止，防災，熱工 ネルギーの有効利用などによる生活環境の整備を目的 としてスタートしたもので, 今後, 増大する民生用エ ネルギーの中で大きなウエイトを占めるものと考兄ら れたため，蓺供給事業法が制定され，その健全な発展 が指向された次第であるが，革業の実態は必ずしも当 初予想した姿のようにはなっていない。

一方，民生用エネルギーの中に占める暖房用エネル ギーの比率は今後も增加する傾向にあるといわれてい るが，現在このエネルギーを賄う然料は漂とんどが石 油である点が，今後の石油確保状況からみて大きな問 題を提起しているといえる。
このよらな背景のもとで都市熱エネルギー対策の一 環として，熱供給事業の方り万方間われるのは当然と 思われる。

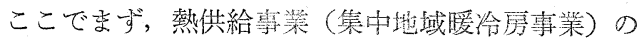
効果を整理してみたい。

従来の個別方式に比べた効果をならると表 5 のと おりである。

まず第 1 に環境効果である。公害発生源の減少，大 型プラントの効率運転による污染物質排出量の削減, 個別機器では難しい公害防止対策の容易化などがあげ られ，さらに効率向上に伴ってエネルギー使用量の削 減に連がる。

第 2 に利便効果がある。需要側建物ではボイラー, 冷凍機, 冷却塔, 貯油槽などが不要となり建物スペー スの有効利用蚛よび省力化が図られるととるに，集中 化に伴らエネルギー管理機能の精度向上が期待でき る。 
第 3 に経済効果としては, 設備の集中, 大型化によ るスダールメリットとして, 建設費の節減が可能とな り, さらに, 個別需要家の負荷に時間的ズレがあるた めプラント容量は小さくてすみ, これによる設備削減 も期待できる。

第 4 に安全性效果が市るが，集中化による防災上の 利点はいらまでもない。

第 5 亿省資源, 省エネルギー効果を特筆したい。効 率向上に伴ならエネルギー使用量の削減はいらまでも なく, 近時特に関心が寄せられているのは, 工場廃熱 の利用その他未利用エネルギーの有効活用の方向であ る。ぬた, 夏の冷游用エネルギーを電力から都市ガス そよる熱供給への切替光, 石炭の採用などによる脱石 油化の可能性もある。

以上のように熱供給事菜を全体としてみた場合の利 点は多々あり, エネルギー政策, 都市の環境政策なぞ の観点からみて, 今後共々の促進を図って行く必要性 については異論がないといえよう。

そこで，今後の熱供給事業の方向を示す動きを二, 三紹介することとしたい。

(1) 現在実施されている熱供給事業はすべて地方自 治体の住宅, 都市政策上の指導に基ついて推進されて いるといえるが，最近における東京都の地域暖冷房計 画区域の指定および同計画の策定の動きは注目に值す る。

東京都は, 昭和 45 年11月, 公害防止条例の全面改正 に際して, 地域暖泠房計画を大気污染対策として, 同 条例に計画区域の指定および加入協力義務について規 定したが，その後同48年には地域暖冷房推進区域を発 表すると共に, さらに同52年, 計画推進の指導標準並 びに計画区域の指定に関する要綱を作成して, 手続面 の整備を完了した。同指導標準の第一の目的は, 地域 暖冷房のプラントスペースを確保することであり，こ の方策として前述の推進区域内にあって建築計画面積 が抒括む放 3 万 $\mathrm{m}^{2}$ 以上の建物の新改筑をしようとする 者に対し，プラントスペースの提供を要請することが 規定された。なお，この場合の地域暖冷房の適正規模

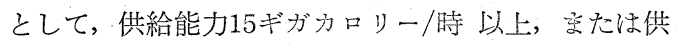
給床面積の合計が 20 万 $\mathrm{m}^{2}$ 以上一応の目安としてい る。

これにより東京都は，まず，すでに熱供給事業が害 施されている(1)大手町地区, (2)西新宿地区, (3)内圭町 地区の 3 地区を第一次分として昭和54年 2 月に区域指 定を行ったが，その後現在まで 7 地区の指定が行われ ている。
地域ぐるみの公害対策として地域暖冷房の導入が推 進されているが，大気污染防止をはじめとする諸効果 は，地域全体の合意と協力が西って初めて発揮される ものであるため, 東京都は事羓推進の指導に当っても この点を重視し，地元説明会などを重ねて地元のコン センサスを得るよら努めているといらことである。

（2）民生用エネルギー需要は，居住環境の改善，问 上が社会的要請である限り, 今後一層增大すると考克 られ，この需要增に対する安定的なエネルギー供給は 当面の大きな政䇾課題の一つである。

近い将来にも予想されている石油供給危機を前提に すれば，民生用エネルギーに関する脱石油化の促進は 重要な課題となってくるが，民生用の石油代替エネル ギーの新技術開発は, 経済性, 地域的条件などの側面 から短期間での普及には限界があるといわれている。

しかしながら，地域的な熱供給といらパターンによ れば，各種廃熱の有效利用あるいは天然ガス，石菂使 用などで脱石油化が相当の規模で可能と考えられる。 このような背景のもとに, エネルギー資源の多様化を 図る観点も含めて，都市ゴミ燒却炉，工場などからの 廃熱を熱供給事の熱源として有効利用を図ろらとする 検討が関係者の間で熱心に進められている。

その一例として, 通産省資源エネルギ一厅が実施し た「昭和54年度石油適正化調査（地域廃熱利用システ 么調查)」がある。本調查は資源エネルギー庁が (財) 省エネルギーセンターに委託して行ったものである が，現在，工場，ゴミ燒却施設などに和ける廃熱利用 は所内利用という形で行われているものの, 回収廃熱 の蕰度が低い場合には，利用する熱需要が所内で络十 分に存在しないため，大量の廃熱を廃棄せざるを得な い反面，暖房給湯等の民生用熱需要は，産業用に比べ れば低い温度でも十分に賄らことが出来ることから， 工場廃熱の内部利用が困難であっても，周辺に大きな 民生用熱需要が存在すれば，廃熱を供給することによ って，地域スケールでの省エネルギー化が可能となる ため,このような地域廃熱利用システムの可能性につ いて検討したものである。

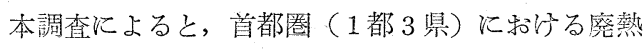
回収量（地域熱源として利用可能な廃熱回収量）は， 工場廃熱(旧熱管理指定工場449件を対象にした実態調 查により，廃熱回収対象工場数は 35件）で年間 4,182 $\times 10^{9} \mathrm{kcal}$ (石油換算で 44 万 $\mathrm{k} \ell$ 程度), ゴミ焼却施設 (連 続炉保有施設85件を対象とした実態調查により，廃熱 回収対象施設数は 80 件) で，年間 $4,776 \times 10^{9} \mathrm{kcal}$ (石 油換算で 51 万 $\mathrm{k} \ell$ 程度) 合計 $8,958 \times 10^{\circ} \mathrm{kcal}$ (石油換算 
で95万kl程度）の大量の数值になっている。

一方，本調査では廃熱利用の受け皿としての熱需要 地区を, 新規の宅地開発地区, 新規の工業団地開発地 区から抽出し，廃熱源と熱需要地区を適切に組合せる ことにより廃熱利用型地域暖冷房が成立する可能性の 高い地区（立地可能地区）を抽出する検討が行われ た。

この結果, 経済的側面からみた「廃熱輸送限界距 離」を考虑して, 現在のエネルギー価格水準でも廃熱 利用型地域暖冷房が成立する可能性が高いと考学られ る地区が 17 所検出された。廃熱源別にみると工場廃 熱型 4 地区, ゴミ廃熱型11地区, 複合廃熱型 2 地区と なっている。

次いで，これら17地区について廃熱利用システムが 導入された場合の省エネルギー効果が概算されたが， 熱需要量と廃熱量との時間的バランス（日変動につい ては蓄熱システムを前提としているので考慮せず，専 ら季節変動について検討）および配管熱損失などを考 慮した結果，年間およそ10万 $\mathrm{kl}$ (石油換算) のエネル ギー削減が可能であることが示されている。なお，冷 房についても廃熱を利用すれば，エネルギー削減量は さらに 2 割程度増大すると考光られ, さらに, 今後エ ネルギー価格が上昇すれば上記の立地可能地区はさら に増大することになるのでこの検討結果は今後関係者 の注目をあびるものになると思われる。

（3）以上紹介した動きは，熱供給事業を政策的に推 進しょうとする面のそれであるが，実際に事業化を図 る観点からすると, 種々困難な問題があり, その促進 を図るためには，いくつかの課題が上ってくる。

一般に, 熱供給事業は, 都市開発事業, 新住宅地開 発事業に対応して実施されるものであり，現に最近で は地方自治体の都市整備の一環として，地域暖冷施設 を都市施設として都市計画に組入れる例が多い。ま た，熱供給事業は装置産業であり多額の設備投資を要 するものであるが，事業の計画にあたっては，プラン トや導管の規模，配置などについて地域計画との整合 性を保ち, 予想される将来の需要に対し十分な設備を 建設する必要がある上，道路建設と同時に導管を敷設 するなど多額の先行投資が必然的に要求されることに なる。從って, 熱供給事業としては, 地域開発計画完 成迄（ $5 \sim 10$ 年程度の長期間を要する例が多い）の間 は，相当程度の設備の低稼動率を前提として事業を開 始しなケればならない宿命にある。さらに, 往々にし て需要側の建設が当初計画より遅延することがあるの で，相対的に先行投資負担は增大し，収益の低下を招
くことになる。加えて，熱料金については，適正な原 価により算定されることになっているが，需要確保の ためには個別暖冷房コストとの見合いも無視出来ない 実情にある。

以上のような背景から，最近においては地方自治体 などにより地域暖冷房の事業化が図られても, 民間の 投資意欲が激減して和り, 事業主体の決定が難航する 例が多くなっている。

熱供給事業は前述したような各種の政策観点から， 国の施策としてもその普及を促進し，健全な発展を図 る必要があるが，長期の先行投資負担に耐えて事業を 遂行していく宿命にあり，さらに熱需要の顕在化の過 程に沶いて不確定要素がある反面, 事業規模の拡大に 限度があるなどの特殊事情があるため，本来的に民間 資本のみに依存することは無理があるといえる。この ことは, 住宅向け熱供給事業の場合に一層顕 著であ る。従って, 特に住宅向け熱供給事業については, 住 宅もしくは宅地造成に当たる公共機関が当初から事業 に参画して出融資を行ら，いわゆる第 3 七クターの方 式で実施されることが望ましいといえる。

以上のような観点に関連して, 日本住宅公団によっ て検討された結果を簡単に紹介しておきたい。

(「多摩ニュータウン及び筑波研究学園都市に和ける 新都市施設の事業実施方針策定に関する調查報告書」 昭和54年 5 月)。

これは，当該 2 地区に和ける新都市施設の事業化方 策を検討したものであるが，他の地区に拈ける新都市 施設導入の一般解をも模索したものとなっている。こ れによれば, 地域暖冷房施設について次のよらに提言 されている。

「地域冷暖房施設については，需要家にとってのコス トを個別方式と同等とすることが望すしいことから， 先行投資に対する公的助成，開発者負担による事業主 体への助成措置が必須であり，当面は一部開発者負担 (地域負担) による助成を主体として推進するが，公 的助成の拡充が望まれる。」

(4) 現在わが国のエネルギー政策の基本方向として 示されているものは次のと和りである。すなわち，国 際石油情勢が㛜しさを增す中で，エネルギー所要量の 70\%以上を石油に依存し，しかも，そのほとんどを海 外から輸入しているわが国が，引き続き国民経済及び 国民生活の安定的発展を持続していくためには，過度 の石油依存体質を改め，一次エネルギー供給源の多角 化，分散化を図ることによって，エネルギーの安定供 給を確保することが不可欠である。このようなエネル 
ギー・セキュリティの確保および I E A，サミットな どに护看際的合意の遂行を踏まえて，わが国とし ては，1990年度までに石油依存度を50\%に引き下げる ことを目標として，(1)原子力，石炭，L NGなどの石 油代替エネルギーの開発・導入の推進, (2)省エネルギ 一の推進, (3)石油の安定供給確保を柱とする総合エネ ルギー政策の遂行に全力を尽すというものである。

このような大きな課題の中で，熱供給事業をどのよ らに位置付けて，その推進をどのように図っていくか が当面の問題になってくる。

現在，通産省としては，中・辰期な対策，短期的な 対策として数多くの政策課題を揭げ，その推進に努力 をしているところであるが，都市のエネルギー対策の ひとつとして，脱石油化に関連して，ガス冷房の普及 に力を注ぐことにしている。これは都市ガスの主原料 が有力な石油代替エネルギーであるL NGであるた め, 電力の夏季ピーク問題の緩和と同時に電力業界に おける石油消費量の削減に資するというものである が，これは都市ガスを熱源とする熱供給に置き替えて も同様のことがいえるのでこの面の推進が一つの方向 として出てこよう。

さらに，前述した廃熱利用の爇供給パターンの他， いわゆる熱併給発電方式についても真剣に検討すべき 時期に来ているといえる。

わが国の場合, (1)近年建設される火力発電所は, 熱
需要地から遠く離れた過疎地に立地されているものが 多く, (2)熱併給発電所が数多く実現しているヨーロッ パ先進諸国と比較してわが国の気候は温暖であるため 年間の熱需要量が少ない，などの理由から事業用火力 発電所としての熱併給発電所はまだ実現されていない が，近時，各方面で蒸気抽出タービンによる熱併給発 電システム, ガスタービンと蒸気タービンの複合サイ クル熱併給発電システムの調查研究が行われている。 一種のコミュニテイ・エネルギーシステムにおける最 適なトータルバランスの追求であるが，その具体化に ついては，電力側も含めた関係者の強い協力体制が必 要になってくると考えられる。

現在，熱供給事業に対しては，税制面では，工事費 負担金の圧縮記帳，固定資産税の減免措置，財政面で は，日本開発銀行および北海道東北開発公庫による長 期低利融資などの助成措置を実施しているが，通産省 としてはその事業化の一層の促進を図るため, 昭和56 年度財政投融資要求に沶いて, 金利の一層の低減を求 めているところである。

都市熱エネルギーのあり方の問題として, 地方自治 体による都市環境行政，住宅福祉政策などとの関連に おいて，熱供給事業に寄せられる期待は今後益々大き くなるものと予想されるが, 関係者の協力を得てそ の健全な発展のため努力したいと考えているものであ る。

\title{
A Prospect of District Heating and Cooling System
}

\author{
Shinichi NARITA
}

(Agency of Natural Resources and Energy)

SYNOPSIS :- Since 1965, district heating and cooling systems have been installed at many places in Japan.

The Heat Service Law was enforced in 1972 and the systems are installed at 30 places in 1980. The systems, which form a part of urban and residential policies, are installed to utilize heat energy efficiently, to prevent air pollution and to keep the safety and the fine view of cities.

Recently, people are most concerned about the conservation of energy and resources. From this point of view, the district heating and cooling systems will be installed at more places from now on, utilizing the waste heat of factories and the new energy effectively. 